\title{
The Current Rights of Minority Shareholders in Saudi Arabia
}

\author{
Khalid Saad Al-habshan ${ }^{1}$ \\ ${ }^{1}$ School of Law, Brunel University, UK \\ Correspondence: Khalid Saad Al-habshan, School of Law, Brunel University, UK. E-mail: \\ habshan_33@hotmail.com
}

Received: May 5, 2017

Accepted: June 23, 2017

Online Published: October 30, 2017

doi:10.5539/ilr.v6n1p185

URL: https://doi.org/10.5539/ilr.v6n1p185

\section{Overview}

The preceding articles examined the legal framework of corporate governance in Saudi Arabia and the important elements of the institutional framework for Saudi corporate governance. The discussion in this chapter first focuses on government and government-regulated institutions established to enforce compliance and see that the actions of corporations are in line with corporate governance law. This chapter then examines minority shareholdings interests and rights and investigates minority shareholder protection under the CL. In addition, the board of directors is described, which controls and guides firm operations in compliance with corporate governance standards and regulations.

\section{Outline of Minority Shareholdings}

Before discussing minority shareholding in Saudi Arabia, it is first necessary to briefly describe minority shareholdings themselves. The minority does not control the firm's operations by voting (either with others or independently). Of course, the fewer shares firms or individuals possess, the less say they have in the running of the business. If a single shareholder possesses the majority of shares, this shareholder enjoys significant influence over the firm's operations. A majority shareholder can push forward decisions in general meetings and meetings of the board of directors where typically a majority vote determines decisions. ${ }^{1}$

One shareholder wielding significant control over a firm can give rise to serious concerns. The primary concern is that the majority shareholder's influence might result in negative outcomes for the business for which it cannot seek any remedy. ${ }^{2}$ A firm is a separate legal entity from its shareholders, and thus if damage is done to a firm it is only the firm that may seek legal redress. If the action of a director sanctioned by the majority of shareholders causes damage, individual minority shareholders have no recourse to redress this wrong. A firm's actions are frequently directed by the majority shareholder through the decisions made at general meetings. ${ }^{3}$

Minority shareholders might also find that a majority shareholder unfairly treats or oppresses them. This situation arises when the business is operated in a manner detrimental to the minority shareholders' interests. The legal remedies offered for unfair actions of majority shareholders focus on protecting minority shareholders from such actions not on protecting the company from damage. Regardless of the fact that shareholders have a lower stake in the company than the majority shareholder, the minority shareholder also needs to be involved in the disclosure process. For instance, if the majority shareholders proceed to initiate a company project while excluding the minority shareholder, the majority shareholders may be culpable of non-disclosure. Therefore, the minority shareholder may initiate a legal process against majority shareholders based on an irregularity referred to as fraud of minority. ${ }^{4}$ When determining whether an action against a majority shareholder can be pursued, the court considers the equitable issue of valid expectations as well as the lack of confidence between shareholders. The law must offer minority shareholders, as well as firms, potential remedies for any unfair or illegal behaviour which has negative impacts on them. ${ }^{5}$

\footnotetext{
${ }^{1}$ A Hicks and S Goo, Cases and Materials on Company Law (6th edn, Oxford University Press 2008) 429.

${ }^{2}$ S Mayson, D French and C Ryan, Company Law (24th edn, Oxford University Press 2007-2008) 515.

${ }^{3}$ A Reisberg, Derivative Actions and Corporate Governance: Theory and Operation (Oxford University Press 2007) 76-77.

${ }^{4}$ Law Commission (n 67).

${ }^{5}$ Hicks and Goo (n 234) 451.
} 


\subsection{Source of Problems and Current Remedies for the Protection of Minority Shareholders}

The Gulf States have drawn a number of international investors. Indeed, a survey recently revealed that the United Arab Emirates and Saudi Arabia are the best parts of the Arab world to undertake business. In addition, Saudi Arabia is listed among the top twenty nations for conducting business globally. ${ }^{6}$ This survey considered a number of factors: how easy it was to start a business and obtain credit; the degree of protection given to minority investors; and the operation of cross-border trade. ${ }^{7}$ Kjaer recently observed that the business model of these nations is founded on drawing in foreign investment, and thus there is an emphasis on more astute regulation. However, oil revenues and high liquidity, which lead to the quick development of businesses, are also a strong draw for foreign investors. ${ }^{8}$

Thus, it is fair to assume that these nations have developed comprehensive, efficient and easy-to-use systems of company law in order to protect the interests and rights of all parties. Unfortunately, this is not the case with Saudi Arabia. Despite reforms to Saudi Arabian company law, the legal system of Saudi Arabia, as it stands, does not afford adequate protection for minority shareholders. ${ }^{9}$

The Saudi legal system allows minority shareholders to make a complaint against the majority shareholder but not the board of directors about any unfair or illegal behaviour thought to be taking place. ${ }^{10}$ A strict limitation on this right is that any complaint must be made before the behaviour or action that is being questioned is completed. A minority shareholder has no right to seek a review of any behaviour or actions once they have concluded. In addition, a majority shareholder may choose to sanction certain conduct after it has occurred, in which case minority shareholders have no recourse. Typically, courts will take the side of the majority shareholder in order to avoid intervening in the internal operations of a firm. Even when an abuse of power is obvious, only the majority shareholder has the authority to hold directors accountable for their actions or fire a misbehaving director. ${ }^{11}$

As a result, company law in Saudi Arabia does not provide adequate protection of the interests and the rights of minority shareholders. Overall, company law gives majority shareholders unlimited control over a firm's interests and gives explicit powers to minority shareholders to bring a legal action on a firm's behalf against majority shareholders or directors suspected of wrongdoing. This deficit in the protection afforded by legislation leaves it to shareholder agreements to safeguard the interests and rights of minority shareholders.

In Saudi Arabia, shareholders may legally include whatever clauses and terms they wish in shareholder agreements provided that these clauses or terms do not conflict with the relevant company statutes. ${ }^{12}$ Shareholder agreements allow shareholders to protect themselves when dealing with especially disputatious issues. ${ }^{13}$ Serious problems can arise without a well-crafted, written agreement. An agreement can also establish exit processes in case an impasse is reached. This allows a minority shareholder to leave a firm without causing serious disturbance to its operations. In addition, express terms to prevent conflict during the removal or cancellation of the directorship of a minority shareholder can be included in shareholder agreements. ${ }^{14}$

\subsection{Necessity of Protecting Minority Shareholders}

The lowering of trade barriers makes it increasingly simple to invest in businesses across the world. Competition for investment is no longer confined by national boundaries but has become international. As this trend continues, Saudi Arabia has created systems catering to desirable foreign investors. The protection afforded to shareholders by the legal system is a vital determining factor in attracting foreign investment to a specific jurisdiction. ${ }^{15}$ Both foreign and domestic investors need to feel confident that a firm is run by efficient, transparent and honest

\footnotetext{
${ }^{6}$ Saudi Arabia ranked as the top country in the Arab world and 16th overall for conducting business globally, whilst the UAE ranked second in the Arab world and 46th overall. Andrew Foxwell, 'UAE Climbs in World Ease of Business Rankings' (The National, 10 November 2008) $<$ http://www.thenational.ae/business/economy/uae-climbs-in-world-ease-of-business-rankings> accessed 15 January 2009.

${ }^{7}$ Foxwell (n 239).

${ }^{8}$ Jesper Kjaer, General Manager of the private enterprise partnership for MENA at the International Finance Corporation; ibid.

${ }^{9}$ A Naciri, Corporate Governance around the World ( $\left(1^{\text {st }}\right.$ edn, Routledge 2008) 357.

${ }^{10} \mathrm{CL}$ (n 7) Section 28.

11 ibid Section 33(1) and (2).

${ }^{12}$ CL (n 7) Section 27.

${ }^{13}$ H Hamd Allah, Saudi Commercial Law (1 $1^{\text {st }}$ edn, Annahdah 2003) 259

${ }^{14}$ R Cooper, 'How Do You Protect Your Shareholding?' (2005) <http://www.rtcoopers.com!pdflbenefit_oCa_well_dfrafterd shareholders agreement.pdf $>$ accessed 18 October 2012.

${ }^{15}$ B Cheffins, 'Minority Shareholders and Corporate Governance' (2000) 21(2) CL 41.
} 
management, that managers and shareholder receive fair, equal treatment and that a reliable system of protection is in place. ${ }^{16}$ Crucially, a system that effectively protects shareholders' interests and rights, including minority shareholders, is needed. The goal of this system should be to create a mechanism that prevents majority shareholders from misusing their influence and control. Minority shareholders must always have a way to seek relief when necessary. ${ }^{17}$

A number of legal scholars have investigated minority shareholder protection but mostly in relation to different exit processes and the issue of court interference. Virtually no researchers in Saudi Arabia and only a rare few in the UK have explored the philosophical and theoretical reasons for the need to protect minority shareholders' interests and rights.

\subsection{Vulnerability of Minority Shareholders}

To understand how majority shareholders can abuse their influence and control, it is necessary to form a picture of how they can deal with a firm or a minority shareholder. A majority shareholder can make displays of strength in order to obtain personal benefits without any concern for the interests of minority shareholders.

\subsection{Interests and Rights of Minority Shareholders that Require Protection}

This section reviews the rights and interests of minority shareholders and how statutes should recognise and protect them. When investors provide funds to a business, they generally receive particular interests, rights and powers in return. These benefits require protection. 'Investor protection' is understood to refer to the set of laws and rules laid down to protect the interests and rights of investors. It also includes the degree to which legal organisations can ensure the enforcement of relevant laws. ${ }^{18}$ A minority shareholder falls under the term 'investor' and thus must be afforded particular interests and rights by law, which the legal system safeguards. It is reasonable to assume that minority shareholders generally are more inclined to invest in a firm that provides mechanisms for seeking relief should their interests or rights be violated. ${ }^{19}$ Legislation and the effectiveness of the enforcement of the law determine the interests and rights enjoyed by different shareholders and how effectively they are protected. ${ }^{20}$ Thus, a key issue is what powers, interests and rights a shareholder, specifically a minority shareholder, actually holds when purchasing company shares.

To fully understand the precise nature of the interests, rights and powers enjoyed by shareholders, it is first necessary to explain investors' connection to a firm and their interests and rights in it. A 'shareholder' has been defined as an investor who places funds into a firm with the expectation of receiving a return on this investment. $^{21}$ The investment does not represent a direct interest in the firm's assets but a financial interest in the

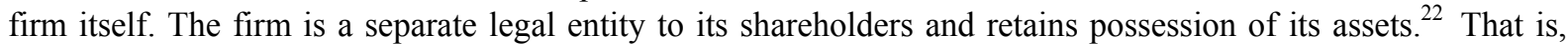
when shareholders place money into a firm, they receive interests, rights and powers in return which can then be used in connection with the business's operations and capital.

The OECD's Principles of Corporate Governance ${ }^{23}$ lists six essential rights that all shareholders should be afforded:

1) The right to safe ownership registration processes;

2) The right to transfer new shares;

3) The right to acquire pertinent information regularly;

4) The right to be active and vote in meetings;

5) The right to remove and elect board members; and

6) The right to share in profits.

The OECD Principles also includes two rights reserved for minority shareholders:

\footnotetext{
${ }^{16}$ L Miles and M He, 'Protecting the Rights and Interests of Minority Shareholders in Listed Companies in China: Challenges for the Future' (2005) 16(7) ICCLR 275.

${ }^{17}$ A Boyle and J Birds, Boyle \& Birds Company Law (6th edn, Jordans 2007) 381.

${ }^{18} \mathrm{M}$ DeFond and M Hung, 'Investor Protection and Corporate Governance: Evidence from Worldwide CEO Turnover' (2003) 42(2) JAR 269.

${ }^{19}$ Miles and $\mathrm{He}$ (n 249) 281.

${ }^{20}$ R La Porta, Florencio Lopez-de-Silanes, Andrei Shleifer and Robert W Vishny, 'Law and Finance' (1998) 106(6) JPE 1116.

${ }^{21}$ E Ferran, Company Law and Corporate Finance (Oxford University Press 1999) 315.

${ }^{22}$ Salomon $v$ Salomon \& Co [1897] AC $22 \mathrm{HL}$.

${ }^{23}$ OECD (n 87) 9. Another final report in consultation with the OECD was issued in 2009 but concentrated mostly on public companies.
} 
1) The right to take legal action against majority shareholders or directors for alleged abuses of power against the company or the minority shareholder; and

2) The right to an understandable, fairly priced exit procedure.

All these interests and rights can be assumed to be automatically bestowed upon shareholders when purchasing even a single share, save for situations in which different provisions are included in the shareholder agreement or constitution of a firm (as they exist when the shares are purchased).

A firm's articles of association or shareholder agreement must allow for the issuing of shares with alternate interests or rights. Rock and Wachter have argued that courts should limit and determine the right to obtain pertinent information regularly. ${ }^{24}$ However, this viewpoint does not recognise that if this right is based in statute, it is much easier for minority shareholders to comprehend and use than if the courts must decide this issue. In addition, minority shareholders need regular updates of relevant information in order to make full use of their other rights. Therefore, legislation should expressly provide for the right to access information so that minority shareholders can enjoy it without interruption and impediment. Indeed, statutes should include all the interests and rights mentioned here to make them easier to protect and to prevent misunderstandings, oversights or lack of awareness.

\subsection{Definition and Scope of Corporate Governance and Protection of Minority Rights}

Minority shareholders can be protected by a number of difference sources, such as ethics, statutes, external control mechanisms, the judicial system, corporate governance principles and regulations, shareholder agreements and the voluntary implementation of an internal code. ${ }^{25}$ Nonetheless, corporate governance stands as the most valuable source of protection of minority shareholders. In addition, corporate governance provides a wide-ranging benefit system for people dealing with a firm. Despite an extensive body of literature on corporate governance, no one definition of the concept has been generally accepted by scholars. The term 'corporate governance' was first used only two decades ago, and its full meaning has not yet been thoroughly analysed. In general, corporate governance is understood to mean the system that controls and directs companies. ${ }^{26}$ This is a very imprecise definition that does not explain the true nature of corporate governance.

Du Plessis has put forward a more detailed definition of corporate governance which attempts to incorporate its various features and tasks. He explains that corporate governance is both the method for regulating and overseeing corporate behaviour and a process for balancing the interests of internal stakeholders and other parties who might be impacted by a firm's activities. According to du Plessis, corporate governance seeks to ensure responsible corporate conduct while maximising company profits and efficiency. ${ }^{27}$ This study benefits from adopting this more precise definition which depicts corporate governance as a comprehensive system that takes into account the interests and rights of all shareholders (and other stakeholders) and makes use of diverse legal areas to ensure their exercise. For example, corporate governance can refer to contract law ${ }^{28}$ when negotiating agreements and to company law when listing and adopting, particularly shareholders' interests and rights. Company and contract laws are vital components of corporate governance as is the ability of regulatory bodies and courts to enforce these laws. ${ }^{29}$

Although this definition is an improvement on previous ones, it does not provide for corporate governance to play a part in supplying legal remedies. The definition needs to be broadened in order to extend the purview of corporate governance beyond firms' internal environment. Most importantly, corporate governance cannot guarantee that it safeguards shareholders' rights and interests if it does not ensure the availability of sufficient remedies. ${ }^{30}$ Before elaborating on the goals and functions of corporate governance, it must be stated that robust

\footnotetext{
${ }^{24}$ E Rock and M Wachter, 'Waiting for the Omelet to Set: Match Specific Assets and Minority Oppression in the Close Corporation' (1999) 24(4) JCL 36.

25 Themistokles G Lazarides, 'Minority Shareholder Choices and Rights in the New Market Environment' (10 July 2009) 1 $<$ http://ssrn.com! abstract=1432672> accessed 24 February 2011.

${ }^{26}$ The UK Cadbury Report (1992) and the South African King Report on Corporate Governance (King Committee on Corporate Governance, 1994) tried to define corporate governance and were mentioned in J du Plessis, 'Corporate law and corporate governance lessons from the past: ebbs and flows: but far from "the end of history ... : Part 1"' (2009) 30(2) CL 43.

${ }^{27}$ du Plessis (n 259) 44.

${ }^{28}$ This has not conflicted with granting states and other parties autonomy of contract to write what they demand. Rather, it advises that the government should have states determine rights and interests regarding specific legal processes for any agreement of this kind in order to preserve and guarantee such rights of minority shareholders.

${ }^{29}$ R La Porta, F Lopez, A Shleifer, R Vishny, 'Investor Protection and Corporate Governance' (2000) 58(1-2) JFE 879.

${ }^{30}$ Miles and $\mathrm{He}$ (n 249) 277.
} 
protection for minority shareholders is not essential to establishing an environment that nurtures good corporate governance practices, as some claim. ${ }^{31}$ In fact, the opposite is true. Protection for minority shareholders is one among many elements that make up corporate governance. Corporate governance is designed to support all stakeholders, not only minority shareholders. ${ }^{32}$ Thus, any definition of corporate governance should highlight that the concept itself supports strong minority shareholder protection.

\subsubsection{The Role of Corporate Governance in Providing Remedies}

The role of corporate governance lies primarily in protecting the goals of corporate governance. In the current context, the goals of corporate governance are to strike a balance between conflicting interests in order to protect minority shareholders and to provide remedies if disputes do arise. Corporate governance must guarantee four key elements to adequately protect minority shareholders.

1) The interests and rights of minority shareholders must be safeguarded, and minority shareholders fairly treated. $^{33}$

2) The litigation processes and mechanisms open to minority shareholders must exist in a clear and straightforward form in law.

3) A remedy should be available for every form of abuse of power and unfair treatment.

4) Minority shareholders must be able to sell their shares at a reasonable price when they decide to exit a firm.

Of all the goals of corporate governance, perhaps the most important is to provide legal mechanisms and remedies in case unfair treatment or abuses of power occur. Corporate governance does not leave minority shareholders to the internal mechanisms of a firm but grants them certain legal remedies. To achieve this goal, the corporate governance structure needs to spread accountability and responsibility among shareholders. ${ }^{34}$ Even so, if a minority shareholder does not have recourse to clearly delineated processes and remedies, holding a malefactor accountable for illegal or harmful behaviour might be impossible. Lazarides has argued that corporate governance must clearly delineate the interests and rights of minority shareholders and establish effective legal, judicial, penal and regulatory systems in order to ensure that minority shareholders can access these remedies and serve the overall goal of protecting such shareholders. ${ }^{35}$

The function of corporate governance in making available particular legal remedies benefits both minority shareholders and the courts by clarifying which remedies are available in a given situation. Courts might not be able to judge a case without restriction and find a just outcome if there are no explicit statutory provisions on the issue. The American case of Wheeler v Pullman Iron \& Steel $\mathrm{Co}^{36}$ is one example of the failure of statutes to deal adequately with company law. In this case, it was decided that the court did not have the power to order the winding-up of the firm in question if that remedy did not already exist in statute. ${ }^{37}$ Inadequate or unclear statutes can change outcomes and result in deep uncertainty and doubt for judges and shareholders alike.

The lack of a statutory mechanism that clarifies legal remedies renders any corporate governance mechanism redundant. ${ }^{38}$ Creating a list of minority shareholder rights and interests but neglecting to implement any legal remedies cannot establish a practical, effective form of corporate governance that offers any real protection. If a majority shareholder were aware that corporate governance gave minority shareholders the ability to pursue real, legal actions to redress wrongs and unfair treatment then that majority shareholder would be dissuaded from acting inappropriately. ${ }^{39}$

To conclude, it is evident that protection for minority shareholders is a significant aspect of corporate governance. To ensure adequate protection, corporate governance must specify litigation remedies and give the courts and

\footnotetext{
${ }^{31}$ DeFond and Hung (n 251) 10.

32 Stakeholders consist of many types of parties, such as majority and minority shareholders, employees, directors, creditors, suppliers, members of the public and others.

${ }^{33}$ OECD ( $\mathrm{n}$ 87) 40. Another final report in consultation with the OECD was issued in 2009 but focused on public companies.

${ }^{34}$ OECD (n 87) 29

${ }^{35}$ Lazarides (n 258) 6.

${ }^{36}$ III 197; 32 NE 420.

${ }^{37}$ In the United States, the court cannot bring justice without an actual statutory footing. Statutes should always empower the court to order winding-up when needed, as the court may not grant a remedy that is not statutory.

${ }^{38}$ Lazarides (n 258) 3.

${ }^{39}$ D Schlimm, L Mezzetti and B Sharfman, 'Corporate Governance and the Impact of Controlling Shareholder' (2010) 18(1) CGA 6.
} 
minority shareholders real power in the running of a firm. There is a positive correlation between corporate governance and protection for minority shareholders; better corporate governance will likely lead to effective protection of minority shareholders. However, if corporate governance is not supported by statutory remedies for all forms of mistreatment and abuses of power then its efforts serve no purpose. Clearly, for any corporate governance system to be effective, it must have a broad foundation that covers all types of wrongdoing. The following section explains the present bases for bringing legal action and why they need to be broadened.

\subsubsection{Present Bases for Bringing Legal Action Regarding Corporate Interests}

Certain grounds recognised and described by statute must be satisfied for a minority shareholder to bring legal action. Fraud is the most common basis for legal action. Indeed, in jurisdictions including Saudi Arabia, fraud is the only clear basis for action by a minority shareholder. Minority shareholders are thus faced with severe difficulties when wrongdoing does not constitute fraud. As there are no specified legal remedies for other acts, such as abuse, misuse and pure negligence, a minority shareholder must prove fraud as a basis for action.

UK common law ${ }^{40}$ provides an example of a system that in the past allowed a minority shareholder to bring an action to court solely due to fraud. UK courts established the common law legal mechanism of a derivative action. This allowed minority shareholders to bring an action on a firm's behalf but only in an obvious case of fraud. ${ }^{41}$ Establishing fraud as the sole basis for legal action was onerously restrictive as all misconduct had to constitute a form of fraud. Unsurprisingly then, case law reveals that only rare actions were brought by minority shareholders against majority shareholders under common law. ${ }^{42}$ The plight of minority shareholders was made all the more difficult as they did not have free access to the information that could have proven that fraud had occurred. Pavlides $v$ Jensen ${ }^{43}$ clearly indicates the importance of proving fraud. In this case, the minority shareholder did not prove that the negligent disposal of assets constituted fraud, and thus it was unsuccessful. However, in the latter case of Daniel $v$ Daniels,${ }^{44}$ the court permitted a derivative action in which only negligence was alleged. The judge in this case appears to have chosen to view the significant profit that a majority shareholder made at the expense of the firm's well-being as selfish negligence that could be seen as a form of fraudulent behaviour. This complex, fragile basis of fraud for a legal action was limited in scope and difficult to apply in practice, allowing numerous instances of mistreatment and abuse of power to stand. ${ }^{45}$

Finally, in the latter part of the twentieth century, a number of reviews ${ }^{46}$ demonstrated that restricting the grounds for a legal action to fraud alone had negative effects. In response, a number of proposals and suggestions were advanced to broaden the scope of liability to include numerous other forms of misconduct beyond fraud. These proposals also aimed to eliminate the need to prove that a malefactor was in control of a firm in order for an action to be brought. The Companies Act 2006 incorporated all of these suggestions. The statute states that a derivative action may be brought not only in cases of fraud but also those involving a breach of trust or duty, abuse, negligence, misuse or default. Fraud does not have to be proven; each instance of misconduct, in and of itself, can form the basis of an action.

To conclude, the history of UK law should serve as a useful lesson for jurisdictions that accept only fraud as a suitable basis for a legal action regarding corporate misconduct. The need to include a broader range of bases on which a minority shareholder can bring an action should be considered because of the benefits that widening the scope of actions can bestow on firms themselves. If a wider approach is not taken, numerous examples of wrongdoing will go unpunished to the detriment of the companies involved.

\subsubsection{Towards an Optimal Protection Model}

Jurisdictions across the world overwhelmingly use one model (of only two) for protecting minority shareholders. The first model is used in civil law countries, including France, the United Arab Emirates, Saudi Arabia, the Netherlands, Italy and Spain, while the second is used in common law countries, including the UK, the US, India, and Canada. The first model is a French model, and the second is based mostly on UK law and thus is referred to as the Anglo-Saxon model. Common law nations offer shareholders relatively greater legal protection from

\footnotetext{
${ }^{40}$ This is no longer the case in English company law as this device has been moved to the statute under the Companies Act 2006 instead of common law.

${ }^{41}$ Reisberg (n 236) 337.

42 M Almadani, 'Derivative Actions: Does the Companies Act 2006 Offer a Way Forward?' (2009) 30(5) CL 135.

${ }^{43}$ [1956] 2 All ER 518. Fraud affecting the minority was also seen in Daniels v Daniels [1978] Ch 406; All ER 89 Ch D.

${ }^{44}$ Daniels v Daniels [1978] Ch 406.

45 Almadani (n 275) 132.

${ }^{46}$ Law Commission Report 1997 \& Company Law Review, Developing the Framework, 2000.
} 
mistreatment than civil law nations. ${ }^{47}$ However, pre-emptive measures are more effective in civil law nations than common law jurisdictions. Pre-emptive rights ${ }^{48}$ are designed to avoid the issue of below-market share prices and to ensure that shareholdings are not diluted. However, in common law nations, these rights are not very effective. Overall, common law jurisdictions are preferable for minority shareholders. Lazarides has argued that other legal systems cannot manage and monitor firms in the same way as common law systems and that the better protection afforded by common law jurisdictions is due to the specific legal protections they give to minority shareholders. ${ }^{49}$

Compared to other legal systems, common law jurisdictions offer a set of laws that provides the highest level of protection for minority shareholders - primarily their access to various legal mechanisms. ${ }^{50}$ For example, the UK grants minority shareholders five mechanisms:

1) Personal action: Minority shareholders can bring a personal action if their rights have been violated. ${ }^{51}$

2) Derivative action: Minority shareholders can bring a derivative action if the interests of the company have been damaged. ${ }^{52}$

3) Oppression/unfair prejudice action: Minority shareholders can bring an unfair prejudice action in instances where an action by a firm damages their interests in their capacity as a member of the firm. ${ }^{53}$

4) Winding-up order: Minority shareholders may pursue a winding-up order when doing so is equitable and fair..$^{54}$

5) Investigation request: A minority shareholder may request that a firm be investigated when its operations are not being dealt with properly (this occurs most frequently in relation to public firms). ${ }^{55}$

A review of the forms of protection available under different jurisdictions and legal systems provides important information about the establishment of an optimal model of minority shareholder protection. The following six principles are essential to ensuring the minimum protection of minority shareholders' interests and rights.

1) When minority shareholders have a reasonable belief that their or the firm's rights have been infringed, they must have access to straightforward legal mechanisms to seek redress. ${ }^{56}$

2) A minority shareholder must be able to bring an action on the firm's behalf in relation to a wide variety of types of inappropriate behaviour.

3) The courts must be empowered to deal effectively with shareholder conflicts and to intervene and make enforceable decisions if needed.

4) Majority shareholders should not have decision-making control when it comes to litigation. Instead, when a firm's interests are mishandled or when a shareholder wishes to enforce the rights owed to the firm, the issue should be handed over to the courts, which can dismiss nuisance claims brought by shareholders.

5) Clear exit procedures must be put in place. These must offer a reasonable price for shares and be carried out in a timely manner.

6) The practical realities of protection for minority shareholders must be reviewed and evaluated so that any required legal reforms can be addressed immediately.

\footnotetext{
47 La Porta, Lopez-de-Silanes, Shleifer and Vishny (n 253) 1116.

${ }^{48}$ Preemptive rights generally give the shareholders of a particular company priority in purchasing any new shares or those of a shareholder who wishes to sell before they are made available to the public or require board approval for a transfer.

${ }^{49}$ Lazarides (n 258) 4.

${ }^{50}$ La Porta, Lopez-de-Silanes, Shleifer and Vishny (n 253) 1129.

${ }^{51}$ This action, in particular, is still available under English common law. See, e.g. Smith v Croft No 2 [1988] Ch 114 and Prudential Assurance Co Ltd v Newman Industries Ltd (No 2) [1982] Ch 204.

${ }^{52}$ This action used to operate under English common law but was made a statutory action under the Companies Act 2006.

${ }^{53}$ This action used to be under Section 459 of the Companies Act 1985 but now comes under Section 994 of the Companies Act 2006.

${ }^{54}$ For example, see Insolvency Act 1986 Section 122(1)(g). This is the last option available to the minority shareholder who must first prove that doing so is just and equitable.

55 The action has a basis in the Companies Act, Section 431(1) and (2). Some amendments were made to the Companies Act 2006 to give the power of investigation to the Secretary of State under Section 77

${ }^{56}$ OECD (n 87) 40. Another final report in consultation with the OECD was issued in 2009 but focused on public companies.
} 
Legislators must keep in mind these principles when drafting statutes with provisions designed to protect minority shareholders. It is extremely challenging for legislators to balance minority shareholders' need for protection (and thus the ability to sometimes check majority shareholder actions) and majority shareholders' need for the room and licence to effectively operate a firm. ${ }^{57}$ That is, legislators constantly struggle to take into equal account all the different interests at play. A similar problem confronts the courts and judges when they decide upon disputes between different shareholders. Of particular difficulty are cases when it is not in a firm's best interests for litigation to go forward successfully but a minority shareholder has the right to bring an action. $^{58}$

\subsection{Minority Shareholder Protection under Saudi Company Law}

The Saudi Commercial Code is based on the French system although some scholars have argued that the system implemented by the Gulf States is an adaptation of the legal system transmitted by the Ottoman Empire that controlled this region. ${ }^{59}$ This viewpoint can help explain why Saudi Arabian company law does not reflect the precise provisions found in contemporary French company law and why Saudi company law deals with a number of corporate bodies not present in French law or civil law jurisdictions. Egyptian legal experts made additional refinements to the French commercial system on top of the Ottoman changes, establishing the French/Egyptian model which Saudi Arabia adopted as the foundation for its company legislation. ${ }^{60}$ Of course, Saudi Arabian law does not exactly match the French/Egyptian model as Saudi legislators selected what they considered the most appropriate provisions given the unique character of the country's commercial experience. Islamic jurisprudence, known as Sharia law, has and continues to have a dominant influence over Saudi Arabian company law. Sharia law sets down fundamental principles covering all facets of the law. ${ }^{61}$ Thus, Saudi company law draws on a number of different sources, all of which have left their mark.

Saudi Arabian councils (e.g. the Panel of Experts, Shura (Consultatory) Council and the Council of Ministers) ${ }^{62}$ and legislators have focused on improving the country's commercial environment in order to make the economy more diverse and less reliant on oil. ${ }^{63}$ The Foreign Capital Investment Law $2000^{64}$ is a clear example of this attitude. This flexible, practical law improved the situation for foreign capital investments in the country. The primary goal of this law is to promote and facilitate foreign investment in order to make Saudi Arabia an open market for interested parties.

Saudi company law has also attempted to establish adequate protections for shareholders of public firms who now have the statutory right to seek a legal remedy against directors. ${ }^{65}$ Sections 76,77 and 78 of the CL state, respectively, that if the directors' handling of company operations results in abuse, wrongdoing or misuse, they are jointly liable to compensate the firm or its shareholders. A liability action ${ }^{66}$ may be filed by the company against its directors if their actions have harmed the position of all shareholders who take this action on the firm's behalf. A liability action against the directors may also be brought by each shareholder should the directors' actions have caused specific damage to the shareholder in question. Shareholders can only bring such an action if the firm's right to litigate remains valid, and they must inform the firm that they are bringing the action.

Although the government of Saudi Arabia has pledged to reform various fields, including the field of trade, no significant changes have been made to the CL. Its efficiency continues to decline as it fails to direct attention to numerous key aspects of the rights of shareholders in listed organisations. In this situation, the Saudi legislature

\footnotetext{
${ }^{57}$ L Sealy and S Worthington, Cases and Materials in Company Law (5th edn, Oxford University Press 2001) 371.

${ }^{58}$ H Hirt, 'The Company's Decision to Litigate Against Its Directors: Legal Strategies to Deal with the Board of Directors' Conflict of Interest' (March 2005) JBL 194.

59 El Sheikh (n 101) 76.

${ }^{60} \mathrm{R}$ Lewis and $\mathrm{C}$ Mallat, 'Commercial Law in the Middle East' (Centre of Islamic \& Middle Eastern Law) $<$ http://www.soas.ac.uklCentres!IslamiclawlMaterials.html> accessed 12 February 2013.

${ }^{61}$ The influence of Sharia law on the Saudi CL will be discussed in the next section.

${ }^{62}$ The process of making a law starts with the Panel of Experts within the Shura (Consultatory) Council, which debates and discusses the proposed draft of the law to see if any changes or amendments are needed. Otherwise, the draft is sent to the Council of Ministers for final review and then approval.

${ }^{63}$ El Sheikh (n 101) 22.

${ }^{64}$ The Cabinet approved this law on 10 April 2000 to replace a complicated investment law that restricted foreign capital investment to certain narrow economic sectors.

${ }^{65}$ Sections 76, 77 and 78 of CL deal with shareholders' right to litigate against directors for a variety of reasons.

66 'Liability action' is the English translation from Arabic of the action available in public companies.
} 
should make decisions to improve the Kingdom's investment environment and, in particular, to provide greater protection to investors in joint-stock companies. Such decisions will likely encourage investment in the Saudi financial market. ${ }^{67}$

Despite a number of major amendments, the main limitations of the CL have not been resolved to the satisfaction of the local businessmen and foreign investors who firmly disapprove of the current law. Strongly criticised, this law now lags behind modern advances in commercial activities and is especially dissonant with the Saudi government's privatisation strategy, efforts to attract foreign investment and accession to the World Trade Organization, which demands that national laws meet the requirements of international trade. In 2007, the Saudi government developed the final draft of a new law intended to supplant the old one. However, seven years later, the new law has not been promulgated. Its ratification by the Council of Ministers is pending. ${ }^{68}$

The considerable attempts to amend the CL have not met substantial success for various reasons, chief among them are bureaucratic setbacks and centralised decision-making. The lack of significant changes to the law so far is confounding, especially given the pressure from numerous specialists and professionals. At the moment, the law is seriously outdated and includes an insufficient number of provisions. This renders it unsuitable for implementation. Some have claimed that the CGR addressed these limitations to a certain extent. However, the $\mathrm{CL}$ forms the basis of a majority of the provisions in the CGR. Moreover, the CGR are not binding or peremptory and are intended only to serve as guidance. Saudi Arabia's experience in business and trade is still limited as it is a developing country. As such, it should seek to learn from the expertise and knowledge of other countries, particularly developed countries such as the UK. When formulating laws, Saudi Arabia would do well to draw inspiration from UK laws, which provide an appropriate model for the structure and content of flexible, modern laws.

Generally, the CL specifies the rights of shareholders but does not guarantee appropriate protection or effective application of them. Therefore, it is necessary to consider a number of related factors to ensure the efficacy of shareholders' rights. Among these, the structure of company ownership, the legal system, cultural and religious customs and the political climate are of particular importance. These factors exacerbate the challenges and problems that affect activity in the commercial and industrial fields. ${ }^{69}$

The level of protection granted to the rights of shareholders is heavily influenced by the structure of ownership:

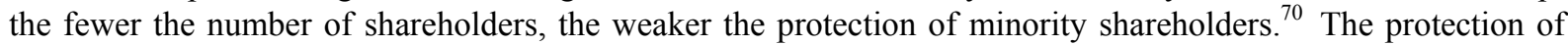
shareholders' rights also depends heavily on the Saudi civil litigation system. A wide range of legal studies have addressed this issue. According to a comprehensive, in-depth analysis, shareholders and creditors in JSCs are more effectively protected from the tactics and manoeuvres of the company board or the majority shareholders in countries that follow a common law system. ${ }^{71}$

On the other hand, in countries that apply the French civil law system minority shareholders have limited power to intervene in the activities undertaken by the corporate managers. ${ }^{72}$ This situation occurs commonly in the Saudi system where majority shareholders' powerful influence on corporate management allows them to pursue their interests without hindrance, completely disregarding minority shareholders and forcing minority shareholders to comply with their actions. Moreover, in Saudi Arabia, the majority shareholders are also usually the company owners because most listed companies began as family companies and later became JSCs. ${ }^{73}$

The CL clearly illustrates this situation as it grants greater control over a company to those who own a larger number of shares. It is generally agreed that the majority shareholders should be afforded greater participation in organisational management than minority shareholders. However, showing complete disregard for minority shareholders and their rights and interests is unacceptable. Considering the principles of justice and fairness, all shareholders should be given fair treatment, regardless of the number of shares they possess, and no group of

\footnotetext{
${ }^{67}$ Yousef Alzahrini, 'Rights of Shareholders under Saudi Company Law 1965' (PhD thesis, Brunel University 2013) 1.

${ }^{68}$ ibid 24.

${ }^{69}$ Jill Solomon and Aris Solomon, Corporate Governance and Accountability (John Wiley \& Sons 2004)

17.

${ }^{70}$ Nabil Baydoun, Neal Ryan and Roger Willett, 'Corporate Governance in Five Arabian Gulf Countries’ (2013) 28(1) MAJ 8.

${ }^{71}$ La Porta, Lopez-de-Silanes, Shleifer and Vishny (n 253) 86.

${ }^{72}$ However, in common law jurisdictions, pre-emption rights are not sufficient to protect shareholders in regards to issuing low-price shares and dilution of their shareholdings, whereas countries that follow the French method have better pre-emption rights. Mahmoud Al-Madani, 'Reforming Minority Shareholder Protection in Saudi Arabia and UAE (Dubai): Does English Company Law Offer a Way Forward?' (PhD thesis, University of Leeds 2011) 59.

${ }^{73}$ Baydoun, Ryan and Willett (n 303) 7.
} 
shareholders should be granted influence and power to the detriment of another group ${ }^{74}$ Although not all shareholders are equal, the equity and rights of the minority shareholders must be acknowledged and respected by the majority shareholders and not infringed under any circumstances.

Therefore, the rights of the minority shareholders must not be diminished or overlooked even though the majority shareholders possess most shares in the company. ${ }^{75}$ In addition, majority shareholders should in no way take advantage of their status to manipulate or direct organisational decisions to serve their interests, especially when such decisions are unfavourable to the interests and rights not only of the minority shareholders but also of the company as a whole.

Thus, when they exercise their right to participate in corporate management and decision-making activities, majority shareholders should not focus on their own interests but on those of the company as it is a business operation whose purpose is to generate financial returns for the shareholders. In addition, the interests of the minority shareholders are no less valuable than those of the majority. Therefore, the majority shareholders should give due consideration to the interests of other shareholder groups, no matter how small.

Amended in 2009, the Global Corporate Governance Principles of the International Corporate Governance Network (ICGN) specify a number of points with regard to these considerations. These principles highlight the need for the fair treatment of all the shareholders of a company and the protection of the rights of all investors. Organisational boards should promote as much as possible shareholders' ability to exercise their rights whilst attempting to eliminate unnecessary obstacles. ${ }^{76}$ Regrettably, the situation is different in many developing countries. For example, in Saudi Arabia, minority shareholders have a weak position in listed companies compared to majority shareholders who have significant influence over and can manipulate management decision-making to serve their personal interests, often without any regard for the company's interests. In these circumstances, it is necessary to emphasis the fact that, although majority shareholders have a stronger position in a company due to the large number of shares they possess, they have no right to abuse this position and the power that comes with it. To prevent such abuse, clear provisions must be made in related laws to keep the power of the majority shareholders in check and ensure fair treatment of all parties.

Both protection and restriction measures should be employed to guarantee justice and fairness. Provisions must protect minority shareholders against any infringement of their rights or interests even if the rights or interests of the minority have not been breached. Most importantly, appropriate legal provisions should ensure that the majority shareholders do not impose their agenda or special interests on the minority shareholders. The power granted to majority shareholders in JSCs entails a set of responsibilities and obligations and should be exercised in a way that is not detrimental to the interests of minority shareholders and the company. ${ }^{77}$

The economic factor also has great importance. A higher level of protection encourages minority shareholders to participate and invest in JSCs. The main interests of any shareholder, whether local or foreign, are financial security and the assurance that the investment made is put to good use by individuals whose priority is accomplishing organisational objectives, not personal interests. Investors' desire to protect their interests and rights is quite understandable. Ultimately, regardless of the length of the investment, the extent to which the company has accomplished its objectives and promoted the interests of its shareholders or favoured the interests of a specific group is always disclosed. In this respect, a company's public reputation is an effective barometer of its performance in achieving those objectives and shareholder interests.

Investors are attracted to make investments in a company for two important reasons: efficient, appropriate protection of shareholder rights and acceptable limitations on their responsibilities. ${ }^{78}$ Although lacking controlling shares in the capital, minority shareholders nonetheless are a key source of capital for listed companies. Therefore, their input should be taken into account, and they should be granted fair treatment. Possessing a large number of shares grants great authority over organisational activities but not more rights than minority shareholders. In addition, legal provisions for the protection of the rights of shareholders aids in the development of companies by stimulating increased liquidity. Consequently, the company does not require creditor loans, thus helping it avoid financially burdensome obligations.

\footnotetext{
${ }^{74}$ Naveen Kumar and JP Singh, 'Corporate Governance in India: Case for Safeguarding Minority Shareholders Rights' (2012) 2(2) IJMBS 8.

${ }^{75}$ Yusuf Alizarin cited in Finweek, 'Shareholders' Rights' (2005) 4-5.

${ }^{76}$ International Corporate Governance Network, 'Global Corporate Governance Principles: Revised' (2009) $9<$ www.icgn.org> accessed 28 June 2013.

${ }^{77}$ L Sealy and S Worthington, Cases and Materials in Company Law (8th edn, Oxford University Press, 2010) 519.

${ }^{78}$ Sealy and Worthington (n 310) 458.
} 
Ensuring the protection of the minority shareholders is considered economically advantageous as it helps increase the national gross domestic product (GDP). ${ }^{79}$ For instance, minority shareholders' investments consolidate and, consequently, increase their savings. When allocated to investment, these savings can stimulate further additional increases in capital. Amending investment regulations thus can improve the business environment, facilitating the flow of capital to areas of high productivity. Therefore, it can be rightly argued that economic growth depends to a significant degree on the protection granted to minority shareholders.

The idea of an inextricable link between national economic growth and the effective protection of shareholders' rights has been proposed by a considerable number of studies on the grounds that adequate protection encourages investment. This leads to improvements in the business environment, such as increased transparency and credibility, which in turn promote financial and economic stability. For instance, the good investment and business reputation of a developed country such as the UK is based in part on the high level of protection of minority shareholders against detrimental manoeuvres by company directors, as well as the existence of solid liability standards and rules. In contrast, manipulation and the pursuit of special interests are rife in countries in continental Europe and the Middle East, including Saudi Arabia. ${ }^{80}$

\section{Saudi Ownership Structure}

The board of directors is vested with the ultimate authority to govern corporations and is primarily responsible for monitoring company activities to verify the implementation of company objectives set by shareholders during the annual GSM. The board is accountable to the shareholders and liable for any misrepresented or falsified information reported to the shareholders and regulators. Along with the board of directors, internal and external auditors and government authorities exert monitoring and regulatory powers over management. ${ }^{81}$

Saudi companies have one-tier boards composed of an odd number of members, from a minimum of three to a maximum of eleven. In a JSC, the board of directors is composed of a majority of non-executive members that possess the appropriate set of skills, technical knowledge or analytical experience. Independent directors make up anywhere from $30 \%$ to $75 \%$ of the board. In most companies, the roles of chairman of the board of directors, $\mathrm{CEO}$, or other executive position, such as managing director or general manager may not be conjoined in one person although it is estimated that two out of every one hundred Saudi companies have a chairman who also serves as chief executive. ${ }^{82}$

The CMA requires that companies annually submit a list of the names, nationalities and other pertinent details of board members and the senior management. Companies must immediately inform the CMA of changes to this roster. The controlling stake in most Saudi firms is concentrated in families, financial and industrial institutions and the government. Ownership disclosure is required, including making publicly available updated lists of major shareholders who own at least $5 \%$ of the company's equity. Shareholders also have the right to be informed of company matters, including inspecting the minutes of the GSM and the report detailing the names and amount of shares held by each. ${ }^{83}$

The ownership structure has implications for an organisation's dividend policies and governance. Studies have demonstrated a significant relationship between dividend declarations and firm performance based on empirical evidence that strongly support the signalling model. ${ }^{84}$ The signalling model asserts that declarations of dividends inform investors about the company's performance and immediately affect investment behaviour involving the company. Investors are loss averse to dividend reductions relative to the reference point set by prior dividends. ${ }^{85}$

A study by Solomon shows that firms listed in the Saudi market also tended to confirm agency theory as evidenced by the significant, positive relationship between dividends and institutional ownership. This relationship has important implications for corporate governance. Institutional ownership through individuals or families tends to support better corporate governance because of the higher level of transparency and disclosure

\footnotetext{
${ }^{79}$ La Porta, Lopez, Shleifer and Vishny (n 253) 137.

${ }^{80}$ Enriques Luca, 'The Law on Company Directors' Self-Dealing: A Comparative Analysis' (2000) 2 ICCLJ 297, 303.

${ }^{81}$ Mohamed Moustafa Soliman, 'Ownership Structure, Board Composition and Dividend Policies-Evidence from Saudi Arabia' (30 April 2013) $<$ http://ssrn.com/abstract=2258399> accessed 24 July 2013.

82 ibid.

${ }^{83}$ Soliman (n 314).

${ }^{84}$ ibid.

${ }^{85}$ Malcolm Baker and Jeffrey Wurgler, 'Dividends are Reference Points: A Behavioral Signaling Model' (Division of Research, Harvard Business School, 2011)<http://www.lse.ac.uk/fmg/events/capitalMarket/pdf/CMW21 M_Baker.pdf> accessed 20 October 2013.
} 
and the greater number of independent members in the board. These factors taken together lead to better performance and, according to signalling theory, higher dividends. ${ }^{86}$

\section{The Board of Directors in the Institutional Framework}

The board of directors manages publicly listed corporations. As it leads the company, the board is accountable for the actions of the entire organisation. Board members are elected by shareholders, usually on an annual basis.

The owners are also the managers and are liable for running their businesses in proprietorships and partnerships. Shareholders own corporations but are not their direct directors because it is illogical to have large numbers of owners making decisions. A small group is needed that can meet regularly and make managerial decisions for the corporation; namely, a board of directors that represents the interests of the shareholders. ${ }^{87}$

\section{The Principal Fiduciary Duties of the Board of Directors}

Sometimes, boards of directors of corporations misuse their powers. Therefore, it is important to have a supervening authority to constrain such behaviour. The international corporate governance frameworks have imposed certain duties and obligations upon corporate board members to keep them working for the interests of shareholders and keep them liable to questioning under company law jurisprudence. ${ }^{88}$

\subsection{General Overview}

The wide-ranging powers granted by law to boards of directors create a perceived risk that these powers might be abused and board members deviate from their objective of stewarding the corporation according to stakeholders' interests. Due to the keen interest of foreign investors, emerging international governance principles have shaped a set of obligations investors expect of boards of directors.

These duties are intended to ensure that board members properly discharge their functions and direct their decisions towards the welfare of the corporation and its stakeholders. The duties of the board as mandated by corporate governance principles support the principal-agent relationship between the board and the shareholders, according to the company and commercial laws of most nations with free market economies. As agents, boards of directors have fiduciary duties to shareholders; that is, they are mandated to manage the corporation in a manner that maximises wealth creation for shareholders.

The CL and CGR make no reference to either the principal-agent relationship or fiduciary duty. This absence is consistent with empirical studies that show that the concept of fiduciary duties has not developed in the Middle East. ${ }^{89}$ In most jurisdictions, fiduciary duties refer to three major duties: the duty of care, the duty of loyalty and the duty to act within one's powers. The OECD Principles of Corporate Governance are consistent with this concept and recognise two important aspects of the board's fiduciary duty: the duties of care and loyalty. While not explicitly mentioned, these duties are implicit in the provisions of the CGR and the CL, as shown in this section.

\subsection{Duty of Care}

The duty of care is a party's legal obligation 'to act towards others and the public with watchfulness, attention, caution, and prudence' in a manner in which a reasonable person in the same circumstances would do. ${ }^{90}$ The duty requires that the board of directors and firm executives make informed decisions by gathering all relevant facts and material, giving them due consideration and then selecting the best option. ${ }^{91}$ The duty of care is incumbent upon board members and is their top-most priority in all matters pertaining to the corporation.

This duty is internationally recognised. For instance, under the UK Companies Act, board members are required to always act with a measure of skill and care reasonably expected of people possessing their knowledge and experience. ${ }^{92}$ The criteria in this definition are subjective because the reasonableness of an action depends a great deal on its specific context and circumstances. The duty of the carer should meet that requirement although

\footnotetext{
${ }^{86}$ Georges Dionne and Karima Ouederni, 'Corporate risk management and dividend signaling theory' (2010) FRL 1-10.

${ }^{87}$ Franklin A Gervutz, 'The Historical and Political Origins of the Corporate Board of Directors' (2004) 33 HLR 89.

${ }^{88}$ David Malcolm, 'Directors' Duties: The Governing Principles' in Ian Ramsay (ed), Corporate Governance and the Duties of Company Director (Centre for Corporate Law and Securities Regulation 1997) 61; Mustafa Kamal, The Joint Stock Company (Arabic edn, Undergraduate House 2001) 68.

${ }^{89}$ Lu'ayy Al Rimawi, ‘Emerging Markets of the Middle East: A Critique of Selected Issues in Arab Securities Regulation' (1999) 7(2) JFRC 160 .

${ }^{90}$ Gerald N Hill and Kathleen T Hill, The People's Law Dictionary (MJF 2002).

${ }^{91}$ Black's Law Dictionary, 'Duty of Care' <http://thelawdictionary.org/duty-of-care/> accessed 23 August 2013.

${ }^{92}$ Hicks and Goo (n 234) 310.
} 
the response may be any one of a number of possible actions.

Unfortunately, in Saudi jurisprudence, the CGR and CL do not explicitly mention the criteria for board members' level of due care in the way that the UK Companies Act does. Therefore, unscrupulous board members can seek cover behind the ambiguity of the law, and regulators and enforcers of the 'duty of care' do not have a clear standard of measure, even a subjective one, by which to judge whether an infraction has been committed. The problem is compounded by the CL provision ${ }^{93}$ that holds a corporation to be bound by all acts of the board of directors considered within the limits of its competence. The duty of care requisite becomes moot when determining whether the limits of competence have been violated because of its lack of definition under Saudi law. Shareholders are left to the mercy of the board's actions, even those patently negligent or careless.

The general rule is that directors are not liable for the actions of the company because it has a separate legal personality. This protection of directors is the corporate veil. However, civil law makes exceptions to this rule. Directors are trusted by the owners of a company, or the shareholders, to make decisions in their interest. These include investment decisions to increase shareholders' wealth. ${ }^{94}$ For example, if a director pursues a business venture without consultation or research and that venture fails, he is personally liable for the loss of money.

Directors who breach their duties can be held liable if the company incurs losses. Therefore, directors need to always carefully consider whether their actions are in the best interests of the company. They must discharge their duties honestly, in good faith and in the best interests of shareholders.

\subsection{Duty of Loyalty}

The fiduciary duty of the board of directors includes the requirement to discharge the duty of loyalty. According to Black's Law Dictionary, this duty is the legal requirement for the board of directors and executives to perform all their actions in good faith and with the best interests of the shareholders in mind. ${ }^{95}$ In practice, this means that the board may not engage in acts that put them in the position of a conflict of interest or engage in acts such as insider trading; whereas the 'duty of care' addresses acts of negligence, duty of loyalty deals with acts of bad faith or malice. Under duty of loyalty, board members may not place their personal interests or those of others before shareholders in the conduct of their duties as fiduciary agents. ${ }^{96}$ Unlike duty of care, however, acts that constitute duty of loyalty are more evident and easily determinable because of their malicious intent.

Duty of care was introduced in October 2006 by the CGR, whose Article 11d orders directors to serve the interest of all shareholders, not just a select group. Moreover, under CGR Articles $4 \mathrm{a}$ and $4 \mathrm{~b}$, shareholders can access all information they need to exert their rights. The CL includes redress mechanisms for shareholders who are entitled to take legal action against directors but the law does not provide such mechanisms for minority shareholders. So far, a liability suit against directors has yet to be filed. ${ }^{97}$

\subsection{Conflicts of Interest among Board Members}

Among board members, conflicts of interest are situations in which the neutrality of board decisions is compromised by considerations of personal interests, whether material or moral, of board members, their relatives and friends. ${ }^{98}$ Conflicts of interest are present when opportunities for formal exploitation to serve private interests arise. ${ }^{99}$ It must be noted that, for a conflict of interest to materialise, the board and members need take no overt action; the very opportunity for personal interest to clash with corporate interest is sufficient. At this point, compliant board members should refrain from participating in deciding the matter or otherwise acting on it.

The CL specified the meaning of conflicts of interest, and these provisions were adopted in the CGR without modification. ${ }^{100}$ The most commonly conceived conflict of interest scenario is board members profiting from a transaction involving the use or disposition of company properties. This is the overt face of conflict of interest. However, there are more subtle situations that should, if they do not already, constitute conflicts of interest

\footnotetext{
${ }^{93} \mathrm{CL}$ (n 7) Article 75.

${ }^{94}$ N Saidi, Corporate Governance in MENA Countries: Improving Transparency and disclosure (Lebanese Transparency Association 2004) 10.

${ }^{95}$ Black's Law Dictionary, 'Duty of Loyalty' <http://thelawdictionary.org/duty-of-loyalty/> accessed 24 July 2013.

${ }^{96}$ Selah Al Ghazali, Conflict of Interest Law: The Necessity (Arabic edn, Kuwait Transparency Society 2008) 15.

${ }^{97}$ WB (n 85).

${ }^{98} \mathrm{Al}$ Ghazali (n 329) 15.

99 Joel Demski, 'Corporate Conflict of Interest' (2003) 17(2) JEP 51

${ }^{100}$ CL (n 7) Articles 68 and 69.
} 
involving board members. For instance, non-executive members of the board are often considered the element that creates balance in board decisions because of the relative disinterest of outsiders to the organisational hierarchy. However, non-executive members are likely to have shareholdings not only in the corporation on whose board they sit but also in potentially competing companies. Non-executive members may even have a greater interest in other companies, even non-competitors, whose interests are contrary to those of the organisation. For example, board members could covertly be pre-empting possible lucrative contracts in their favour or in favour of their more lucrative holdings rather than allowing the natural course of action where the transaction takes place to the benefit of the company they direct. ${ }^{101}$

The CL articles adopted in CGR refinement provisions enforce conflicts of interest restrictions. CGR Articles 18 (a) and (b) exhibit an intention to introduce exceptions to conflict of interest restrictions: ${ }^{102}$

(1) When the board member has secured annual permission from the corporation's shareholders in an ordinary general meeting to perform an act which would otherwise constitute a conflict of interest;

(2) When the board member informs the board and shareholders concerning any private undertakings or commercial contracts performed for the benefit of the corporation; and

(3) When the board member is the primary bidder in a general bidding.

The third instance raises questions about whether such a situation should warrant being made an exception because membership in the board enables one to have knowledge of the corporation's affairs that other bidders do not have, thus creating an unfair advantage. ${ }^{103}$ In all cases, the board member involved must fully disclose to the other board members and the shareholders the full extent of personal interest in any corporate matter.

\subsection{Disclosure of Information by Directors}

Directors must regularly disclose information at least annually or when circumstances have changed. Directors must act in good faith and disclose to the board and external auditors any commercial or external interests that could create a conflict of interest: ${ }^{104}$

- All business interests (direct or indirect) in any other company, partnership or other business venture;

- Membership in trade, business or other economic organisations;

- Shareholdings, share options and/or other interest in the company;

- Any interest direct or indirect in any transaction with the company; and

- Any gifts, monies, commissions, benefits or other favours extended or received from any party.

A director who decides to leaves or is removed from an organisation before the end of the term ought to release the causes of his resignation or elimination to the company's external auditors and, if necessary, to shareholders if the reasons are objection to joint fraud, corruption or other activities or conduct inconsistent with the shareholders' interests. ${ }^{105}$

\subsection{Insider Dealing}

Insider trading occurs when an individual uses knowledge of private information to realise a profit ${ }^{106}$ on the sale of the firm's securities that otherwise could not have been gained. Board members' fiduciary duty requires them to fully disclose to the board and shareholders any information such a member has provided that led to any form of personal gain. ${ }^{107}$ According to the CML, insider information has not been disclosed to the public but is obtained by an individual with legitimate internal access to the firm. If such information were released to the public in an untimely manner, it would have a material effect on the market price of securities. ${ }^{108}$

\footnotetext{
${ }^{101}$ Ben Pettet, John Lowry and Arad Reisberg, Pettet's Company Law: Company Law and Capital Markets Law ( $3^{\text {rd }}$ edn, Pearson Education 2009) 170.

${ }^{102}$ CGR (n 8) Article 18(a) and (b) corresponding to CL (n 7) Articles 68 and 69.

${ }^{103}$ Mohammad Prairie, The Saudi Law of Commercial Transactions (Arabic edn, Institute of Public Administration 2007) 224.

${ }^{104}$ European Corporate Governance Institute, 'Private Sector Initiatives for Corporate Governance: Principles for Corporate Governance in Kenya and a sample of Best Practices for Corporate Governance' <http://www.ecgi.org/codes/documents/principles_2.pdf> accessed on 26 September 2013.

105 ibid.

${ }^{106}$ Black's Law Dictionary, 'What is Insider Trading?' < http://thelawdictionary.org/insider-trading/> accessed 19 October 2013.

${ }^{107}$ Aaron Yoran, Insider Trading in Israel and England (Alpha Press 1972) 15-16.

${ }^{108}$ CML (n 5) Article 50(A).
} 
Insider trading is the act of making personal gains from deliberately trading on securities based on insider information. This takes advantage of the firm's shareholders and tends to destabilise the legitimate workings of the stock exchange by introducing greater volatility in market prices which distorts the true value of stock. Stock market volatility caused by inefficient information dissemination discourages legitimate stock market participants from trusting the Stock Exchange, thus harming the Saudi economy. Generally in Saudi legislation and in international markets, insider trading is considered a crime for which an individual may face fines and imprisonment.

\subsection{Board's Duty to Act within its Powers}

The wide-ranging duties of the board members directly affect corporate governance and how the firm is governed. Left unrestricted by legislation, the board's actions are not monitored within the corporation as the board itself oversees the entire organisation. This opens up the organisation to abuses at the highest levels, a vulnerability which justifies the enactment of restrictions to rein in the vast powers accorded to the board. The UK Companies Act prohibits the board from acting ultra vires, that is, beyond its legal power and authority. The company is a juridical person and may exist only according to its charter or constitution. It cannot exercise any power or perform any act with legal effect that it is not authorised to do so by its constitution or articles of association. So, too, the board of directors, whether acting jointly or individually, is prohibited from acting outside the powers conveyed upon it by its constitution, and these powers may be exercised only for the purpose for which they are given. ${ }^{109}$

The CL also limits the board's powers to the provisions in the CL, the firm's articles of association and to resolutions that are enacted during the corporation's GSM. The CL is cognisant of the power of the board to delegate to one or more of its members the performance of an act or acts within its power. Some restrictions on the board include prohibitions on selling or mortgaging property or relieving the corporation's debtors of their obligations, except when so authorised in the corporation's articles or the CL. ${ }^{110}$

Under the CGR, the board of directors also has the right of delegation to sub-committees, such as nomination, remuneration and audit committees. ${ }^{111}$ The right to delegate does not minimise or absolve the board of directors of the responsibility for these duties. In so delegating the performance of these acts, the board should explicitly define the powers delegated and those reserved for itself because the sub-committees are bound by the limits of the instrument of delegation which empowers them. The work delegated should be within the limits of the board's powers; any delegation beyond the board's jurisdiction is null and void. ${ }^{12}$ Among the other limitations set by the CGR is that the company may not grant a cash loan to any board members or act as guarantor for any loan between any member or members of the board and a third party. ${ }^{113}$ This safeguards investors' capital in the firm against abuses or commingling of funds by members of the board.

\section{Role and Responsibilities within Board Members' Powers}

The board of directors performs the crucial role of providing strategic direction for the company and monitoring management to ensure that all its actions serve the interests of the shareholders. Due to the board's broad powers and accountability to shareholders and company, Saudi regulations consider it the appropriate instrument by which corporate governance practices may be propagated within listed companies. ${ }^{114}$ The Saudi position is consistent with the principles of the OECD and other international conventions that view the board of directors as the repository of accountability for the corporate governance of the firm. The responsibilities of the board of directors include:

(1) Fulfilling their functions according to the company's articles of incorporation, with a duty of care and in good faith; ${ }^{115}$

(2) Representing the shareholders and acting on their behalf and in the interest of the company, for which reason they should not detach themselves from the shareholders but closely identify with their interests; ${ }^{116}$

\footnotetext{
${ }^{109}$ UK Companies Act 2006, Section 171 (a) and (b).

${ }^{110}$ CL (n 7) Article 72.

111 CGR (n 8) Article 13(b).

${ }^{112}$ Sadak Al Jubran, The Joint Stock Company Board of Directors (Legal Publications 2006) 232.

${ }^{113}$ CGR (n 8) Article 18(c).

${ }^{114}$ CL (n 7) Articles 64-82; CGR (n 8) Articles 10-18.

${ }^{115}$ UK Companies Act 2006, Section 172(1).
} 
(3) Training new board members in the skills and competencies necessary to ensure performance of their functions and allow for a smooth transition and continuity; ${ }^{117}$

(4) Consenting to and directing the company's technical policies, such as:

(a) Formulating a full set of policies for the company, including the overall work plans and risk management rules, and conducting regular assessments of these policies,

(b) Deciding on the manner by which the firm can best pursue capital formation, set the company's financial goals and ratify its budgets,

(c) Setting the strategic targets of the firm and monitoring progress towards their attainment,

(d) Conducting a periodic review of internal controls involving the financial and accounting processes in the preparation of financial reports;

(5) Formulating a written policy legitimising relationships with all groups of stakeholders and securing their rights in the company's operations. ${ }^{118}$

The inclusion of the fifth responsibility as an official objective of the CGR means that Saudi law, through the CGR, recognises and marks a major step towards harmonising Saudi standards with those of international corporate governance, in particular the OECD Principles.

\section{Board Membership Categories}

According to the CGR, board members fall into three categories: executive, non-executive and independent members. Executive members hold full-time administrative positions in the corporation and draw monthly salaries. ${ }^{119}$ Non-executive board members hold neither administrative positions nor draw monthly salaries. The CGR stipulates that non-executive members should hold the largest number of board seats and regularly receive information about the corporation's submissions in a satisfactory manner so as to effectively enforce their jurisdictions. ${ }^{120}$

The difference in roles between the executive and non-executive board members is evident. Executive board members know how the company is run. This provides them with a grounded understanding of how optimal corporate performance can be achieved. However, they are beholden to the company, particularly the chief executive, for their livelihood, and thus their decisions might be partial in so far as they affect personal interests. On the other hand, non-executive board members are not as knowledgeable about the company at the operational level but are not as easily influenced because they earn very little from the corporation and therefore can form more independent decisions.

The third type of board member enjoys full independence. The CGR contains strict regulations to prevent any violations of this independence. In Article 2, the CGR forbids a person from sitting as an independent board member if he/she: ${ }^{121}$

(1) Owns a controlling interest or holds the position of senior executive for two years in the company or in one of its subsidiaries;

(2) Owns or is a representative of a legal entity that owns $5 \%$ or more of the company or its group;

(3) Is a board member of any company within the body of the company of which such a member is scheduled to be member of its board;

(4) Has been an employee and a partner of the company or a partner of any other company, including external auditors or senior suppliers, for at least two years;

(5) Is a relative (e.g. parent, spouse or child) of any board member or senior executive of the company or one of its subsidiaries.

\section{Board Meetings}

In Saudi Arabia, board meetings are customarily open to debate in order to improve the board's discharge of its

\footnotetext{
${ }^{116}$ CGR (n 8) Article 11(d).

117 ibid Article 11(f).

${ }^{118}$ CGR (n 8) Article 10(B-1).

${ }^{119}$ CGR (n 8) Article 2.

120 ibid Article 11(G).

121 ibid Article 2.
} 
supervisory tasks in so far as they involve transactions by publicly listed corporations. Open discussions result in a full disclosure of the facts, and when malpractices or questionable dealings are uncovered, open debate provides immediate resolution of such controversies. In addition to such customs, the CGR mandates the following practices during the conduct of board meetings: ${ }^{122}$

1) The board convenes meetings upon the request of the board chairman, who may convene the board for an irregularly scheduled meeting upon the written request by at least two board members. ${ }^{123}$

2) A record of the minutes of the meeting shall be kept, including a tally of votes by agreeing and dissenting members. ${ }^{124}$

3) Sufficient time should be provided for the board to adequately fulfil its duties, inclusive of preparation time for meetings and sub-committee meetings.

4) Board members should be provided documentations in a suitable and timely manner to enable them to sufficiently peruse the material before board meetings.

The CGR does not require any specific number of meetings, and this has allowed the boards of several companies to be remiss in holding meetings. This diminishes the effectiveness of boards as oversight bodies and increases the opportunities for mismanagement. ${ }^{125}$ The CL stipulates that for the meetings of the board to be valid at least half but no less than three members must be in attendance unless the company's article of association provide for a higher number. To be adopted, the resolutions of the board must be approved by a majority of the directors present. In case of a tie, the chairman's vote decides the vote unless the articles of association state otherwise. ${ }^{126}$

\section{Board Sub-Committees}

Many fundamental precepts of the CGR are drawn from international corporate governance principles. Among these sources, the Cadbury report states that in order for a board to be effective it must be appropriately structured and governed by a defined set of procedures. This structure and procedures are realised by the appointment of committees tasked with specific oversight functions, including audit, remuneration and nomination. ${ }^{127}$ CGR Articles 12 to 15 mandate the creation of at least two obligatory sub-committees. These are discussed in the following sections.

\subsection{Audit Committee}

The idea of the audit committee as a fixture of the board of directors was first broached in 1978 when the New York Stock Exchange (NYSE) began to require all listed corporations to establish an audit committee comprised of independent members. ${ }^{128}$ The task of the audit committee is to monitor the missions of the corporation and act as a watchdog. Its aims are to ensure accountability inside the corporation and to protect the company's investors. It does so primarily by ensuring that the corporation's accounting and auditing procedures remain consistent and compliant with standards. ${ }^{129}$ Benefits expected from effective oversight by an audit committee include higher quality financial statements; a culture of self-control which discourages fraud; and empowerment of non-executive board members to have a constructive voice in the governance of the corporation. The CGR specifies four compulsory elements of the audit committee: ${ }^{130}$

(1) It must have at least three members.

(2) Members should either be non-executive or independent members. Corporation executives may not be on the audit committee.

(3) Audit committee members should be sufficiently qualified and possess the skills required in the accounting, auditing and finance professions.

\footnotetext{
${ }^{122}$ CGR (n 8) Article 2.

${ }^{123}$ CL (n 7) Article 79.

124 ibid Article 82.

125 James Westphal and Edward Zajac, 'The Symbolic Management of Stockholders: Corporate Governance Reforms and Shareholders Reactions' (1998) 43 Administrative Science Quarterly 177.

${ }^{126} \mathrm{CL}$ (n 7) Articles 79 and 80.

${ }^{127}$ CL (n 7) Articles 64-82; CGR (n 8) Articles 10-18.

${ }^{128}$ Zabihollah Rezaee, Kingsley Olibe and George Minmier, 'Improving Corporate Governance: The Role of Audit Committee Disclosures' (2003) 18 MAJ 530.

${ }^{129}$ ibid.

${ }^{130}$ CGR (n 8) Article 14.
} 
(4) Members should have neither direct nor indirect interest in the submissions and contracts of the corporation.

The CGR lays out the essential functions of the audit committee: ${ }^{131}$

1) To assist in planning a written statement to the internal audit system, control such internal audit system and confirm its usefulness;

2) To advocate to the board the discharge and appointment of external auditors with their corresponding remunerations;

3) To examine, jointly with the external auditor, the corporation's audit plans; and

4) To verify the external auditor's comments in the board's annual financial report and to issue official opinions on the basis of this report.

\subsection{Nomination and Remuneration Committee}

The nomination and remuneration committee is tasked with the following functions: ${ }^{132}$

(1) Advise on the appointment of new board members, determining that such board members embody honour and honesty when assuming their position on the board;

(2) Update the required capabilities and qualifications for board membership;

(3) Evaluate the strengths and weaknesses of the board and its structure and recommend possible improvements;

(4) Investigate the independence of the board's non-executive and independent members;

(5) Ensure that conflicts of interest do not exist within the board; and

(6) Formulate the procedures by which the remuneration of board members and top executives is determined.

The major task of the remunerations committee is to set the pay for executive members of the board so it risks being a self-serving committee that acts only in its own interests. Therefore, in order to guard against conflicts of interest it is mandated that the majority of its members be independent and non-executive directors. However, members of the nomination and remunerations sub-committee are themselves placed in their positions by the board so they might feel beholden to those executive members.

The framers of the CGR appear to have overlooked the fact that it fails to (1) specify how the sub-committee members should be compensated; (2) set a minimum number of members for the nomination and remunerations committee as for the audit committee; and (3) set a standard level of maximum executive compensation, such as linking executive compensation to the performance of the firm. ${ }^{133}$ These shortcomings open the independence of the board up to question, and the uncertainties in the composition of the nomination and remunerations committees introduce structural uncertainties in the legitimacy of their decisions.

\subsection{Board Members' Compensation}

The payment of board members is a statutory right founded on the principle that the performance of functions must be accorded rightful compensation. Compensation levels are set in the UK through the Combined Code but not in Saudi legislation. ${ }^{134}$ The UK Code states that the level of remuneration should be adequate to attract, retain, and motivate directors to maintain the quality of the successful company, but in no case should the remuneration be in excess of what is necessary. Most importantly, the pay of executive directors must be correlated with their individual performance, as well as that of the corporation. ${ }^{135}$ The pay-for-performance link is a crucial corporate governance practice which has gained widespread acceptance globally, especially after the 2008 economic crisis when exiting bank executives received huge bonuses while their companies went bankrupt or took government bailouts.

In Saudi Arabia, a 1992 Ministerial Resolution limits the maximum remuneration for non-executive and

\footnotetext{
${ }^{131}$ CGR (n 8) Article 14(C).

${ }^{132}$ ibid Article 15(C).

${ }^{133}$ Richard Greenbury, Directors' Remuneration: Report of a Study Group (Gee 1995) 23.

134 ibid 24.

${ }^{135}$ UK Combined Code 2008, Section 1.
} 
independent members to the equivalent of $\$ 53,333$ per member and an $\$ 800$ fee for attending board meetings. ${ }^{136}$ The majority of listed companies generally ignored the resolution. However, it did spark a debate about the matter of maximum executive compensation. The Saudi Consultative Council (i.e. the legislative body with jurisdiction over commercial and corporate rules) declared that the annual compensation for board members, including executives, should not exceed $\$ 133,333 .{ }^{137}$

The CGR itself sets no maximum limits on board members' compensation. Theoretically, listed companies are required to submit a written record of the proposed compensation, on which shareholders vote during the legally mandatory GSMs. The CGR also requires that the articles of association of firms describe how the compensation of board members is determined and awarded, inclusive of salaries, bonuses and other payments. ${ }^{138}$ However, the majority, if not all, listed companies have arbitrarily set the compensation of board members. In 2011, 33 corporations paid US\$32 million to their board members while their companies took a loss. These salaries also violated the CL provision ${ }^{139}$ that companies may pay compensation to board members only after distributing a dividend of not less than $5 \%$ of the company's capital to shareholders. Companies that incurred losses could not distribute dividends to shareholders but, nonetheless, board members granted themselves substantial compensation.

\section{Corporate Governance and Comparison}

Corporate governance in countries such as Saudi Arabia is esoteric. Although awareness of it is increasing, corporate governance in Saudi Arabia is still inferior to the US and UK systems. Most Saudi firms are family controlled instead of board controlled. However, the situation has improved in the past decades. ${ }^{140}$

Haniffa and Cooke discuss corporate governance in emerging economies. ${ }^{141}$ The banking sector in Saudi Arabia has been found to have the best corporate governance. ${ }^{142}$ Good corporate governance entails financial reporting, and due to globalisation some firms in Saudi Arabia use the internet to inform their stakeholders about their corporate governance practices, including financial reporting. ${ }^{143}$

Normally, business institutions in emerging markets can be understood with agency theory and the effect of CEO duality. It has been observed that CEO duality does not positively affect business organisations with large boards and low top management ownership but institutional ownership does. CEO duality can work in the context of smaller boards overseeing large management staff as the management decide on a CEO without hesitation and lengthy discussions. As a result, not only in Saudi Arabia but also in most Middle Eastern countries and Egypt, companies are reducing their boards and increasing top management ownership.

Differences exist between common law and civil law countries and between common law and Islamic law countries such as Saudi Arabia. Corporate governance is at higher levels in common law countries, and disclosure is positively associated with corporate governance. ${ }^{144}$ The size of the capital market also decides the extent of disclosure and nature of corporate governance. Enlarging the capital market could encourage management to adhere to good corporate governance and make necessary financial disclosures. As most Saudi firms are smaller than US and UK ones, vertical growth could enhance corporate governance. In addition to the size of the capital market, the "legal and institutional environment also plays a crucial role in shaping corporate governance'. ${ }^{145}$

Corporate governance also depends on shareholding patterns. As mentioned, family-owned businesses do not have the same standards of corporate governance as board-controlled businesses. In another finding, economic reforms played a role in reducing shareholding concentrations. ${ }^{146}$ Thus, the economic reforms had, and still have, a positive effect on corporate performance in Saudi Arabia. In addition, the imposition of corporate governance regulation prompts voluntary corporate social disclosure practices. In the absence of regulation, companies have

\footnotetext{
${ }^{136}$ Ministry of Commerce and Industry Resolution, No 1071, dated 5 May 1992.

137 Aleqt Newspaper (15 March 2011) Issue 6364; Al-Riyadh Newspaper (15 March 2011) Issue 15604.

${ }^{138}$ CGR (n 8) Article 17.

${ }^{139}$ CL (n 7) Article 74.

${ }^{140}$ M Tsamenyi \& S Uddin, 'Introduction to Corporate Governance in Less Developed and Emerging Economies' (2008) 8 RAEE 1.

141 ibid 2.

142 ibid 4.

143 ibid 4.

144 ibid 5 .

145 Tsamenyi and Uddin (n 373) 5.

146 ibid 5-6.
} 
no necessity to disclose financial information.

Financial disclosure by corporate houses in Saudi Arabia has improved since 2006 and is gradually following US and UK corporate governance. However, social and cultural factors prevent Saudi Arabia from simply adopting US and UK regulations of corporate governance and disclosure practices. The conditions that existed in Saudi Arabia before globalisation are 'likely to render imported Western corporate governance models unworkable'. ${ }^{147}$ However, globalisation has changed the situation and, due to necessity, the Saudi government has started making regulations to put disclosure and good corporate governance into practice. ${ }^{148}$

\footnotetext{
147 ibid 6.

148 ibid 6-7.
} 